\title{
STUDI ANGKA KUMAN HANDLE PINTU DI BAGIAN RUANG PERAWATAN MAWAR KELAS III RSUD PROF. Dr. MARGONO SOEKARJO PURWOKERTO TAHUN 2016
}

\author{
Indah Rakhmi Prafitri ${ }^{1)}$, Budi Utomo ${ }^{2)}$ \\ Jurusan Kesehatan Lingkungan, Politeknik Kesehatan Kemenkes Semarang \\ Jl. Raya Baturaden KM 12 Purwokerto, Indonesia
}

\begin{abstract}
Abstrak
Angka kuman adalah suatu mikroorganisme atau mikroba yang biasanya patogenik. Cara pemeriksaan angka kuman dengan metode usap handle pintu adalah dengan mengamati dan menghitung pertumbuhan koloni pada media PCA setelah di inkubasi selama $2 \times 24$ jam. Tujuan penelitian ini adalah untuk mengetahui angka kuman handle pintu di Ruang Perawatan Mawar Kelas III RSUD Prof. Dr. Margono Soekarjo Tahun 2016. Metode penelitian ini adalah penelitian observasional dengan analisis deskriptif yaitu memeriksa angka kuman pada handle pintu ruang perawatan Mawar kelas III kemudian menganalisis faktor-faktor yang mempengaruhi adanya kuman pada handle pintu di RSUD Prof. Dr. Margono Soekarjo Tahun 2016. Hasil pemeriksaan angka kuman pada handle pintu ruang kamar $61.632,5 \mathrm{kol} / \mathrm{cm}^{2}$, ruang kamar $7900 \mathrm{kol} / \mathrm{cm}^{2}$, ruang $\mathrm{kamar} 8632,5 \mathrm{kol} / \mathrm{cm}^{2}$, ruang isolasi 2550 $\mathrm{kol} / \mathrm{cm}^{2}$, ruang isolasi $3647,5 \mathrm{kol} / \mathrm{cm}^{2}$. Sehingga didapatkan rata-rata angka kuman pada handle pintu 872,5 $\mathrm{kol} / \mathrm{cm}^{2}$. Rata-rata suhu adalah $27,9^{\circ} \mathrm{C}$, rata-rata kelembaban adalah 90,6 \%, rata-rata pencahayaan adalah 363,64 lux, rata-rata orang yang menggunakan handle pintu adalah 5 orang/jam. Kesimpulan penelitian adalah ruang perawatan mawar kelas III belum sepenuhnya memenuhi syarat dilihat dari kualitas fisik lingkungan. Peneliti menyarankan sebaiknya pihak rumah sakitmelakukan pembersihan terhadap handle pintu yang ada dirumah sakit menggunakan desinfektan dan memperhatikan kondisi lingkungan agar tetap bersih.
\end{abstract}

Kata kunci : kuman, handle

\begin{abstract}
Number of germ according to Michael J. Pelczar is a microorganism or microbe that is normally pathogenic.The number of bacteria examination method by a method wipe the door handles is observing and counting the colony growth on PCA medium after incubation for $2 \times 24$ hours. The purpose of this study was to determine the number of germ on the door handle Class III Lounge Mawar Care Hospital Prof. Dr. Margono Soekarjo 2016. The Methods of this study was an observational study with descriptive analysis is to check the number of bacteria in the treatment room door handle Mawar class III then analyzes the factors that influence their germs on door handles in hospitals Prof. Dr. Margono Soekarjo 2016. The results of the examination number of bacteria on the door handles 6 room space $1632.5 \mathrm{kol} / \mathrm{cm}^{2}$, living room $7900 \mathrm{kol} / \mathrm{cm}^{2}$, living room $8632.5 \mathrm{kol} /$ $\mathrm{cm}^{2}$, isolation room $2550 \mathrm{kol} / \mathrm{cm}^{2}$, isolation room $3647.5 \mathrm{kol} / \mathrm{cm}^{2}$. So we get the average number of germ on the door handles $872.5 \mathrm{kol} / \mathrm{cm}^{2}$. The average temperature is $27,9{ }^{\circ} \mathrm{C}$, average humidity is $90.6 \%$, the average illumination is 363.64 lux, the average person using the door handle is 5 people / hour. Conclusion of the research that Mawar class III is not fully qualified views of the physical quality of the environment. Researcher suggest, should do a cleansing of the door handle was in the hospital with a disinfectant and pay attention to environmental conditions in order to keep it clean.
\end{abstract}

Key words : germ, handle

\section{PENDAHULUAN}

Kuman menurut Micahel J. Pelczer adalah mikroorganisme yang biasanya bersifat patogenik. Sifat inilah yang dapat menimbulkan penyakit. Habitat kuman sangat beragam baik di lingkungan air, tanah, udara maupun di permukaan suatu benda. Salah satu tempat yang banyak terkontaminasi oleh kuman adalah rumah sakit. Rumah sakit merupakan sarana pelayanan kesehatan, tempat berkumpulnya orang sakit maupun orang sehat, atau dapat menjadi

1) Email : irakhmi@gmail.com

2) Email : budut17@yahoo.co.id tempat penularan penyakit serta memungkinkan terjadinya pencemaran lingkungan dan gangguan kesehatan. Setiap kegiatan yang dilakukan di rumah sakit sangat rentan untuk tejadinya penularan penyakit karena faktor lingkungan yang sangat mendukung baik melalui udara, air, semua alat media dan benda yang berada dirumah sakit seperti di sprei, dinding, meja kerja, jendela, atap, lantai maupun pegangan pintu atau handle pintu. Contohnya adalah RSUD Prof. Dr. Margono Soekarjo dan ruang 
perawatan mawar kelas III merupakan bagian dari rumah sakit yang memberikan pelayanan non medis. Ruang ini memiliki 10 kamar dan disetiap kamar memiliki handle pintu, yang digunakan sebagai media untuk mempermudah sesorang untuk masuk dalam ruangan tersebut. Pada umumnya pengguna handle pintu tidak pernah menyadari bahwa ternyata handle yang digunakan mengandung kuman. Hal ini dapat terjadi karena adanya aktivitas antara tangan pengguna yang satu dengan yang lain berbeda dan adanya kuman udara yang menempel, selain itu handle pintu tidak pernah dibersihkan oleh pihak cleaning service. Berdasarkan permasalahan tersebut maka peneliti tertarik untuk melakukan penelitian dengan judul "Studi Angka Kuman Handle Pintu di Ruang Perawatan Mawar Kelas III RSUD Prof. Dr. Margono Soekarjo Tahun 2016”.

\section{BAHAN DAN METODE PENELITIAN}

a. Bahan Penelitian

Bahan utama yang digunakan adalah media PCA (Plate Count Agar) yang digunakan untuk sel jasad renik yang ditumbuhkan di media agar.

b. Metode Penelitian

Penelitian observasional dengan analisis deskriptif yang bertujuan untuk mengetahui angka kuman handle pintu dibagian ruang Perawatan Mawar kelas III RSUD Prof. Dr. Margono Soekarjo.

\section{III.HASIL DAN PEMBAHASAN}

\section{Hasil}

Pada penelitian ini dilakukan 5 tempat ruang perawatan Mawar, yaitu dengan mengukur suhu, kelembaban, pencahayaan, menghitung orang yang menggunakan handle pintu dan mengambil sampel handle pintu untuk pemeriksaan angka kuman. Penelitian ini dilakukan 2 kali yaitu antara jam istirahat pasien dan jam besuk pasien.

Tabel 1.1 Sanitasi Ruang Perawatan

\begin{tabular}{llll}
\hline No & $\begin{array}{c}\text { Nama ruang } \\
\text { perawatan }\end{array}$ & Nilai & Kriteria \\
\hline 1 & Ruang kamar 6 & $82,5 \%$ & Baik \\
\hline 2 & Ruang kamar 7 & $82,5 \%$ & Baik \\
\hline 3 & Ruang kamar 8 & $85 \%$ & Baik \\
\hline 4 & Ruang isolasi 2 & $85 \%$ & Baik \\
\hline 5 & Ruang isolasi 3 & $85 \%$ & Baik \\
\hline & Rata-rata & $84 \%$ & Baik \\
\hline
\end{tabular}

Tabel 1.2 Hasil Pengukuran suhu

\begin{tabular}{|c|c|c|c|}
\hline No & Nama ruang & Waktu pengukuran & $\begin{array}{c}\text { Suhu } \\
\left({ }^{\circ} \mathrm{C}\right)\end{array}$ \\
\hline \multirow[t]{2}{*}{1.} & Ruang kal & . 18 Juni 2016 (09.30) & 1. 27 \\
\hline & & 18 Juni 2016 (12.00) & 2. 28 \\
\hline \multirow[t]{2}{*}{2.} & Ruang kamar 71 & . 18 Juni 2016 (09.41) & 1. 27 \\
\hline & & 18 Juni 2016 (12.16) & 2. 28 \\
\hline \multirow[t]{2}{*}{3.} & Ruang kamar 81 & . 18 Juni 2016 (09.53) & 1. 27 \\
\hline & & 18 Juni 2016 (12.27) & 2. 30 \\
\hline 4. & Ruang isolasi 21 & . 18 Juni 2016 (10.06) & 1. 27 \\
\hline
\end{tabular}

2. 18 Juni $2016(12.37)$ 2. 28

5. $\quad$ Ruang isolasi 3 1. 18 Juni 2016 (10.17) 1.27 $\begin{array}{ll}\text { 2. } 18 \text { Juni } 2016(12.47) & 2.30\end{array}$ Rata-rata 18 Juni 2016 27,9

Tabel 1.2 Hasil Pengukuran kelembaban

\begin{tabular}{|c|c|c|c|}
\hline No & $\begin{array}{l}\text { Nama } \\
\text { ruang }\end{array}$ & Waktu pengukuran & $\begin{array}{c}\text { Kelembaban } \\
(\%)\end{array}$ \\
\hline \multicolumn{2}{|c|}{ 1. Ruang } & 1. 18 Juni 2016 (09.30) & 1.92 \\
\hline \multicolumn{2}{|c|}{ kamar 6} & 2. 18 Juni 2016 (12.00) & 2. 92 \\
\hline \multirow{2}{*}{\multicolumn{2}{|c|}{$\begin{array}{l}\text { 2. Ruang } \\
\text { kamar } 7\end{array}$}} & 1. 18 Juni 2016 (09.41) & 1.92 \\
\hline & & 2. 18 Juni 2016 (12.16) & 2. 92 \\
\hline \multirow{2}{*}{\multicolumn{2}{|c|}{$\begin{array}{l}\text { 3. Ruang } \\
\text { kamar } 8\end{array}$}} & 1. 18 Juni 2016 (09.53) & 1.92 \\
\hline & & 2. 18 Juni 2016 (12.27) & 2. 85 \\
\hline \multirow{2}{*}{\multicolumn{2}{|c|}{$\begin{array}{l}\text { 4. Ruang } \\
\text { isolasi } 2\end{array}$}} & 1. 18 Juni 2016 (10.06) & 1.92 \\
\hline & & 2. 18 Juni 2016 (12.37) & 2. 92 \\
\hline \multirow{2}{*}{\multicolumn{2}{|c|}{$\begin{array}{l}\text { 5. Ruang } \\
\text { isolasi } 3 \\
\end{array}$}} & 1. 18 Juni 2016 (10.17) & 1.92 \\
\hline & & 2. 18 Juni 2016 (12.47) & 2. 85 \\
\hline & ata-rata & 18 Juni 2016 & 90,6 \\
\hline
\end{tabular}

Tabel 1.2 Hasil Pengukuran pencahayaan

\begin{tabular}{|c|c|c|c|}
\hline No & $\begin{array}{l}\text { Nama } \\
\text { ruang }\end{array}$ & Waktu pengukuran & $\begin{array}{c}\text { Pencaha } \\
\text { yaan (Lux) }\end{array}$ \\
\hline \multirow[t]{2}{*}{1.} & Ruang & 1. 18 & 1. 446,4 \\
\hline & kamar 6 & 2. 18 Juni 2016 (12.00) & 2. 270 \\
\hline \multirow[t]{2}{*}{2.} & Ruang & 1. 18 Juni 2016 (09.41) & 1. 415,2 \\
\hline & kamar 7 & 2. 18 Juni 2016 (12.16) & 2. 525,8 \\
\hline \multirow[t]{2}{*}{3.} & Ruang & 1. 18 Juni 2016 (09.53) & 1. 776,2 \\
\hline & kamar 8 & 2. 18 Juni 2016 (12.27) & 2. 777,8 \\
\hline \multirow[t]{2}{*}{4.} & Ruang & 1. 18 Juni 2016 (10.06) & 1. 102 \\
\hline & isolasi 2 & 2. 18 Juni 2016 (12.37) & 2. 107 \\
\hline \multirow[t]{3}{*}{5.} & Ruang & 1. 18 Juni 2016 (10.17) & 1. 125 \\
\hline & isolasi 3 & 2. 18 Juni 2016 (12.47) & 2. 91 \\
\hline & Rata-rata & 18 Juni 2016 & 363,64 \\
\hline
\end{tabular}

Tabel 1.2 Hasil Perhitungan jumlah pengguna handle pintu

\begin{tabular}{|c|c|c|c|}
\hline No & $\begin{array}{l}\text { Nama } \\
\text { ruang }\end{array}$ & Waktu pengukuran & $\begin{array}{c}\text { Jumlah } \\
\text { pengguna } \\
\text { handle } \\
\text { pintu/jam }\end{array}$ \\
\hline \multirow[t]{2}{*}{1.} & Ruang & 1. 18 Juni 2016 (09.30) & 1. 0 \\
\hline & kamar 6 & 2. 18 Juni 2016 (12.00) & 2. 6 \\
\hline \multirow[t]{2}{*}{2.} & Ruang & 1. 18 Juni 2016 (09.41) & 1. 3 \\
\hline & kamar 7 & 2. 18 Juni 2016 (12.16) & 2. 0 \\
\hline \multirow[t]{2}{*}{3.} & Ruang & 1. 18 Juni 2016 (09.53) & 1. 0 \\
\hline & kamar 8 & 2. 18 Juni 2016 (12.27) & 2. 24 \\
\hline \multirow[t]{2}{*}{4.} & Ruang & 1. 18 Juni 2016 (10.06) & 1. 2 \\
\hline & isolasi 2 & 2. 18 Juni 2016 (12.37) & 2. 0 \\
\hline \multirow[t]{3}{*}{5.} & Ruang & 1. 18 Juni 2016 (10.17) & 1. 5 \\
\hline & isolasi 3 & 2. 18 Juni 2016 (12.47) & 2. 10 \\
\hline & Rata-rata & 18 Juni 2016 & 5 \\
\hline
\end{tabular}

Tabel 1.2 Hasil Pemeriksaan angka kuman

\begin{tabular}{cccl} 
No Nama & Waktu pengukuran & $\begin{array}{l}\text { Jumlah } \\
\text { Angka } \\
\text { Kuang }\end{array}$ & $\begin{array}{l}\text { Kuman } \\
(\text { koloni/ } \\
\left.\mathbf{c m}^{2}\right)\end{array}$ \\
\hline
\end{tabular}




\begin{tabular}{llll}
\hline 1. & Ruang & 1.18 Juni $2016(09.35)$ & 1. 860 \\
& kamar 6 & 2.18 Juni $2016(12.05)$ & 2. 2.405 \\
\hline 2. & Ruang & 1.18 Juni $2016(09.46)$ & 1. 1.460 \\
& kamar 7 & 2.18 Juni $2016(12.21)$ & 2. 340 \\
\hline 3. & Ruang & 1.18 Juni $2016(09.58)$ & 1. 235 \\
& kamar 8 & 2.18 Juni 2016(12.32) & 2. 1.030 \\
\hline 4. & Ruang & 1.18 Juni $2016(10.11)$ & 1. 860 \\
& isolasi 2 & 2.18 Juni 2016 (12.42) & 2. 240 \\
\hline 5. & Ruang & 1.18 Juni 2016 (10.22) & 1. 310 \\
& isolasi 3 & 2.18 Juni 2016(12.52) & 2. 985 \\
\hline & Rata- & 18 Juni 2016 & 872,5 \\
& rata & \\
\hline
\end{tabular}

\section{Pembahasan}

Berdasarkan hasil observasi rata-rata sanitasi ruang perawatan adalah $84 \%$ termasuk dalam kategori baik. Untuk hasil rata-rata pada saat pengukuran diperoleh yaitu suhu adalah $27,9^{\circ} \mathrm{C}$, kelembaban adalah 90,6\%, pencahayaan adalah 363,64 lux, orang yang menggunakan handle pintu adalah 24 orang/jam dan hasil pemeriksaan angka kuman adalah 872,5 koloni/ $\mathrm{cm}^{3}$. Dilihat dari kondisi fisik secara observasional handle pintu terbuat dari bahan stainless, kuat, utuh, masih dapat berfungsi dengan baik, lapisan sudah mulai mengikis, dan handle pintu tidak pernah dibersihkan. Berdasarkan KEPMENKES RI No. 1204/MENKES/SK/X/2004 tentang Persyaratan Kesehatan Lingkungan Rumah Sakit bahwa standar bahwa hasil pengukuran suhu, kelembaban dan pencahayaan masih belum memenuhi standar persyaratan. Hal ini terjadi dikarenakan oleh beberapa faktor seperti sirkulasi udara yang kurang lancar, adanya fun yang tidak berfungsi dengan baik dan adanya sinar matahari yang langsung masuk kedalam ruangan sehingga suhu meningkat.

Berdasarkan rata-rata hasil perhitungan angka kuman handle pintu di ruang perawatan Mawar Kelas III adalah 872,5 kol $/ \mathrm{cm}^{2}$. Persyaratan angka kuman handle pintu tidak ada, sehingga kami membandingkan dengan angka kuman udara, dimana menurut KEPMENKES RI No. 1204/MENKES/SK/X/2004 tentang Persyaratan Kesehatan Lingkungan Rumah Sakit bahwa standar angka kuman udara di ruang perawatan adalah 200$500 \mathrm{CFU} / \mathrm{m}^{3}$. Perbandingan angka kuman handle pintu dengan persyaratanlain yaitu KEPMENKES RI No. 1204/MENKES/SK/X/2004 tentang Persyaratan Kesehatan Lingkungan Rumah Sakit bahwa standar angka kuman lantai di ruang perawatan adalah 5-10 $\mathrm{CFU} / \mathrm{m}^{2}$. Adanya dua peraturan tersebut antara angka kuman udara dan lantai, maka angka kuman handle pintu lebih tinggi dari persyaratan keduanya. Udara merupakan sesuatu yang kompleks dimana intensitas untuk kontak langsung dengan manusia lebih banyak di bandingkan dengan intensitas penggunaan handle pintu dan lantai. Namun dilihat dari angka kuman yang melebihi angka standar keduanya maka tetap ada kemungkinan dapat terjadi penularan penyakit. Angka kuman dapat dipengaruhi karena adanya aktivitas manusia salah satunya adalah berkunjung ke ruang perawatan sehingga sangat memungkinkan setiap orang membuka pintu. Selain itu juga adanya kemungkinan penyakit infeksius yang diderita oleh pasien yang membutuhkan perawatan intensif sehingga perawat dan dokter sering pula menyentuh handle pintu untuk masuk.

Suhu, kelembaban, pencahayaan juga mempengaruhi angka kuman handle pintu yang dapat menjadi berkembangnya kuman patogen meningkat selain itu handle pintu tidak pernah dibersihkan, oleh karena itu untuk mengurangi indeks angka kuman handle pintu perlu dilakukan pembersihan terhadap handle pintu secara berkala dengan menggunakan desinfektan. Kegiatan lain yang perlu dilakukan adalah dengan menambah fan dan exhauster dalam ruang perawatan yang belum ada, hal ini dilakukan agar kelembaban ruangan stabil, dan menambah jumlah penggunaan AC. Selain itu perlindungan individu juga perlu diperhatikan yaitu dengan sering mencuci tangan menggunakan sabun atau menggunakan aseptic gel pada saat di lingkungan rumah sakit.

Debu dapat menjadi penularan penyakit ketika seseorang kontak dengan permukaan yang terinfeksi. Dimana orang dapat terkena infeksi melalui:

a. Droplet yang kering terdapat di dalam debu, seperti dalam sprei, pakaian, alat-alat rumah tangga.

b. Menginfeksi tangan dengan menyentuh atau mengorek hidung, menggunakan saputangan, atau dengan penggunaan handle pintu yang mengandung kuman.

c. Beberepa mikroorganisme dapat bertahan di dalam debu untuk beberapa hari atau minggu jika tidak terkena cahaya matahari secara langsung. (J.M Gibson, MD, 1996, h.3)

Partikel debu kebanyakan masuk dan melekat pada handle pintu melalui tangan manusia yang menyentuh handle pintu pada saat membuka pintu. Kuman penyakit ini dapat hidup dan berkembang dilingkungan rumah sakit seperti: udara, air, lantai, makanan dan benda-benda medis maupun non medis (jendela, tempat tidur, tirai, pintu dan handle pintu) (Catur Wulan, 2012, h.61).

Menurut penelitian Farida Juliatina dan Shofyatul Yumna (2008, h.27)kuman dapat dijumpai disekitar kita baik di air, udara, benda-benda yang ada bahkan pada tubuh tiap orang. Sebagian besar kuman merupakan bakteri, namun ada juga jamur dan mikrooragnisme lain. Pada keadaan normal dan sehat, organisme tersebut tidak berbahaya bahkan dapat bermanfaat. Mikroorganisme tersebut disebut juga dengan flora normal. Flora dibagi menjadi 2 yaitu flora normal mikroorganisme sementara dan mikroorganisme tetap. Flora mikroorganisme sementara yang terdiri dari non patogen dan potensial patogen yang tinggal di kulit atau mukosa selama kurun waktu tertentu (jam, hari, minggu), berasal dari lingkungan yang terkontaminasi atau pasien karena 
jumlahnya lebih sedikit. Salah satunya flora mikroorganisme sementara ada di kulit, dimana mikroorganisme yang menempati suatu daerah tanpa menimbulkan penyakitpada inang yang ditempati. Setiap mikroorganisme memiliki jumlah tertentu untuk dapat menyebabkan penyakit, contohnya Staphylococcus aureus dapat menyebabkan penyakit jika telah mencapai 1.000 .000 atau $10^{6}$ per gram.Adanya populasi jamur juga ditemukan di flora mikroorganisme tetap. Sebagian mikroorganisme tetap tidak berbahaya. Untuk dapat menghilangkan mikroorganisme sementara dapat dilakukan dengan cara mencuci tangan dengan menggunakan sabun.

\section{IV.KESIMPULAN}

a. Hasil pengukuran suhu, kelembaban dan pencahayaan pada ruang perawatan Mawar kelas III di RSUD Prof. Dr. Margono Soekarjo Purwokerto, yaitu:

1. Suhu pada ruang perawatan Mawar kelas III antara $27^{\circ} \mathrm{C}-30^{\circ} \mathrm{C}$. Suhu ruang perawatan Mawar kelas III tidak memenuhi syarat yaitu $22^{\circ} \mathrm{C}-24^{\circ} \mathrm{C}$

2. Kelembaban pada ruang perawatan Mawar kelas III antara 85 \% - 92 \%. Kelembaban ruang perawatan Mawar kelas III tidak memenuhi syarat yaitu $45 \%$ - 60\%.

3. Pencahayaan pada ruang perawatan Mawar kelas III antara 91-777,8 lux. Pencahayaan ruang perawatan Mawar kelas III sebagian sudah memenuhi syarat dan sebagian tidak memenuhi syarat standar yang berlaku yaitu $100-200$ lux.

b. Hasil perhitungan orang yang menggunakan handle pintu pada dua waktu antara jam istirahat pasien dan jam besuk yaitu 24 orang.

c. Kondisi sanitasi berupa kontruksi bangunan, kualitas fisik ruang perawatan, hygiene karyawan, sarana dan prasarana pada ruang perawatan Mawar kelas III termasuk dalam keadaan baik yang sudah memenuhi standar KEPMENKES RI Nomor : 1204/MENKES/SK/X/2004 tentang persyaratan Kesehatan Lingkungan Rumah Sakit.

d. Hasil pemeriksaan angka kuman handle pintu pada ruang perawatan Mawar kelas III adalah antara 235 - 2.405 koloni/cm².

\section{DAFTAR PUSTAKA}

Catur Wulan Febriyanti, 2012, Studi Komparasi Angka Kuman Pada Handle Pintu dan Ruang Administrasi di Rumah Sakit Umum Daerah Kebumen Tahun 2012, Purwokerto: Kementrian Kesehatan RI Politeknik Kesehatan Semarang Jurusan Kesehatan Lingkungan Purwokerto

Departemen Kesehatan RI, 1993, Persyaratan Kesehatan Lingkungan Rumah Sakit, Dirjen PPM dan PLP, Jakarta
Departemen Kesehatan RI, 2002, Keputusan Menteri Kesehatan Republik Indonesia No: 1204/MENKES/SK/X/2004 Tentang Persyaratan Kesehatan Lingkungan Rumah Sakit, Jakarta: Departemen Kesehatan RI

Farida Juliantina dan Shofyatul Yumna, 2008, Perbandingan Angka Kuman pada Cuci Tangan dengan beberapa Bahan Sebagai Standarisasi Kerja di Laboratorium Universitas Islam Indonesia

http://informasibangunan.blogspot.co.id/2013/05/daft ar-harga-handle-pintu-solid.html di akses jam $\underline{16.25}$ wib, tanggal 20 Januari 2016

http://www.depobangunan.co.id/tips\%20perawatan\% 20handle\%20pintu.html diakses jam 16.57 WIB, tanggal 20 Januari 2016

http://www.angzcommerz.com/product-blog/caramerawat-handle-pintu/ diakses jam 16.59 WIB, tanggal 20 Januari 2016

http://eprints.uny.ac.id/8796/3/BAB\%202\%20\%2007413244039.pdf diakses jam 11.07 wib tanggal 26 januari 2016

http://inasholihah2006-laporanpraktikumgizi.blogspot.co.id/2014/08/laporanpraktikum-mikrobiologi-pangan 5 .html diakses jam 8.14 WIB tanggal 27 januari 2016

http://rumahidamanminimalissederhana.com/handlepintu-rumah-minimalis-inilah-caramemilihnya/ diakses jam 14.04 WIB tanggal 29 Januari 2016

https://id.wikipedia.org/wiki/Kuningan_\%28logam\% 29\#cite_note-1, diakses pada jam 14.29 WIB tanggal 29 Januari 2016

J.M. Gibson, MD., 1990, Mikrobilogi dan Patologi Modern untuk Perawat, Jakarta: Penerbit Buku Kedokteran EGC

Michael J. Pelczar, dkk.1988. Dasar-Dasar Mikrobiologi. Jakarta: Penerbit Universitas Indonesia

Prescott, L. M, J. P. Harley, dan D. A. Klein. 2008. Microbiology. $7^{\text {th }}$ Ed. McGraw-Hill Book Company Inc. USA, p: 156,158-159

Prili Yoshintan, 2015, Studi Angka Kuman Udara Di Ruang Perawatan Kelas III IRNA I RSUD Prof. Dr. Margono Soekarjo Purwokerto Tahun 2015, Purwokerto: Kementrian 
Kesehatan RI Politeknik Kesehatan Semarang Jurusan Kesehatan Lingkungan Purwokerto

Tri Cahyono, 2013, Pedoman Penulisan Proposal Penelitian dan Karya Tulis Ilmiyah/ Skripsi Revisi Ketiga. Purwokerto. Kementrian Kesehatan RI Politeknik Kesehatan Semarang Jurusan Kesehatan Lingkungan Purwokerto
Srikandi,Fardiaz. 1992, Mikrobilogi Pangan I, Jakarta: PT. Gramedia Pustaka Utama

Undang Undang RI, 2009, Nomor 44 Tentang Rumah Sakit fungsi dan Tugas Rumah Sakit 